\title{
TRANSPIRATION RATE OF SCOTS PINE TREES ON VERY OLIGOTROPHIC SOILS OF NORMAL MOISTURE IN RELATION TO DIFFERENT METEOROLOGICAL CONDITION
}

\begin{abstract}
Diana SIDABRIENE், Department of Forest Sciences, Faculty of Forestry and Ecology, Vytautas Magnus University, K. Donelaičio g. 58, 44248 Kaunas Lithuania, diana.sidabriene@gmail.com

Continuous monitoring of the tree ring formation and transpiration throughout the year is crucial for understanding the tree reaction to changes in meteorology, and evaluating its adaptiveness to recent environmental changes. Data were collected from four Pinus sylvestris L. trees which sapflow was measured by the heat wave propagation method using SFM1 sensors (ICT International, Australia) and annual tree stem increment by electronic dendrometer DRL26. Investigation was performed in middle age pine stand on very oligotrophic soil. Meteorological data revealed that 2019 was the year of drought. In this year pine transpiration rate and volume increment were the lowest. However, water was used most efficiently, which means that pines needed less water to produce $1 \mathrm{~cm}^{3}$ of wood. 2020 was characterized as a year of recovery of moisture regime, when during vegetation precipitation increased up to long term value and the mean air temperature was the lowest. Annaul volume increment of pine trees in this year was the biggest, transpiration rate the highest, but WUE was the smallest, indicating that pine used more water to produce $1 \mathrm{~cm}^{3}$ of wood. Obtained data on WUE during different growing season revealed that Scots pine trees are well adapted to recent meteorological condition. Increase in tree diameter reduced values of Scots pine WUE, what means that bigger pine trees used significantly less water to produce $1 \mathrm{~cm}^{3}$ of wood.
\end{abstract}

Keywords: tree sapflow, volume increment, water use efficiency, adaptive capacity

\section{INTRODUCTION}

Questions about anthropogenic effects on the environment, through manipulation of the vegetation, have become increasingly topical in recent decades. The partitioning of absorbed radiation into sensible and latent heat at the Earth's surface is a key process for the climate (Sellers et al., 1997; Higgins and Schneider, 2005). Climate change with increasing air temperature by intensity of $3-6^{\circ} \mathrm{C}$ over 100 years may affect forest sustainability and adaptive capacity to unfavorable environmental conditions such as drought, frost and heat (Lévesque et al., 2014) as well as air pollution by acidifying compounds (Augustaitis et al., 2007a, 2010a, 2010b, 2011; Holmberg et al., 2013, Forsius et al., 2021) and tropospheric ozone (Paoletti et al., 2007, Serengyl et al, 2011, Sicard et al., 2016; Vuorenmaa et al., 2017). Such changes could affect also trees resistance to pest damage (Augustaitis, 2007). Long-term analysis of meteorological data for a gradient from the coastal to eastern inner Lithuania revealed an increase in annual air temperature and precipitation and rising variation in monthly patterns during the period 1981-2020 compared to 1950-1980 (Augustaitis et al., 2018, 2021). The lack of atmospheric humidity is predicted to reinforce negative effect of climate warming in southern and central parts of Europe, meanwhile in northeastern part of Europe, including Lithuania gradual increase in precipitation amount should mitigate this negative effect of climate changes increasing tree increment (Augustaitis et al., 2015, 2018).

The state of knowledge revealed that the widely distributed pioneer species $P$. sylvestris is known as being tolerant to moderate drought effect. Its drought sensitivity depends on site related factors especially on relief, topography and soil characteristics such as rooting and water holding capacity of soils (Levesque et al., 2014). Therefore, the reactions of this considered tree species to extreme meteorological events under different growth conditions differed significantly due to their different strategies (McDowell 2008; Augustaitis et al., 2018; Marozas et al., 2019) when surviving first of all heat and drought episodes (Lévesque et al., 2014; Augustaitis 2021) what quite well indicates their needles spectral reflectance (Masaitis et al., 2013, 2014). This finding well agreed with results obtained on annual scale which indicated that meteorology explained variation in annual pine tree ring width variation more significantly than acidifying compounds (Augustaitis et al., 2007b, 2015, 2018; Juknys et al., 2014).

Continuous monitoring of tree ring formation throughout the year together with the stem sapflow intensity is crucial for the understanding of tree reaction to changes in environmental conditions, such as temperature, soil water content and rainfall. This investigation can be performed by using sapflow equipment (Baumgarten et al., 2019) and automatic dendrometers (Deslauriers et al., 2007; Augustaitis 2021). These equipments provide time series composed of diurnal rhythms of water storage depletion and replenishment which result in general tree ring formation.

Copyright () 2021 The Authors. Published by Vytautas Magnus University. This is an open-access article distributed under the terms of the Creative Commons Attribution License (CC BY 4.0), which permits unrestricted use, distribution, and reproduction in any medium, provided the original author and source are credited. 
Tree transpiration is the major pathway for both water and energy leaving the forest ecosystem. Measurement of transpiration provides access to the canopy conductance of the forest, a key parameter in models of water- and carbonexchange (Collins and Avissar, 1994), since the water and carbon fluxes are strongly linked by their common passage through the stomata (Morén et al., 2001). The sapflow technique (Swanson, 1994) is very useful for obtaining the total water use efficiency (WUE) of a single tree. Sapflow is commonly scaled up to stand level and considered as representing transpiration. A problem with this approach is that, because of the capacitance of the trunk ant branches, sapflow lags somewhat behind transpiration (Granier and Loustau, 1994; Köstner et al., 1996).

To solve the problem which deals with resistance of Scots pine trees during the unfovourable environmental condition, pine tree water use efficiency on the purest for tree growth site condition was analised to the aim to establish their adaptive capacity to recent meteorological condition.

\section{MATERIALS AND METHODS}

Location and stand characteristics. The main research objectives are prevailling in Lithuanian forest Scots pine (Pinus sylvestris L.) trees growing on seaside part of Lithuania in the territory of Nida forest enterprises on poorest for tree growth wind made sandy soils (1 fig).

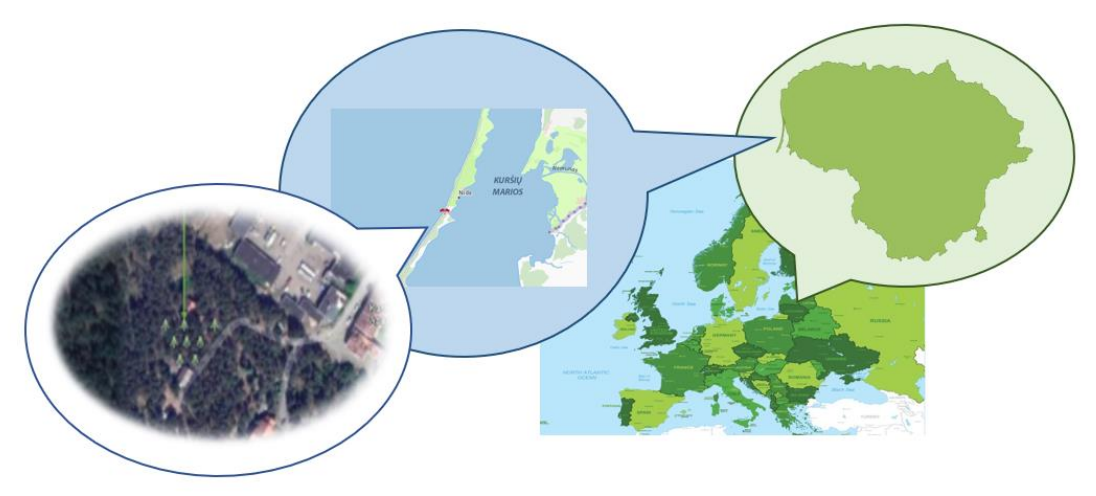

Figure 1. The location of the monitored Scot pie trees

Forest type. Forest site: Oligotrophic mineral soil Forest Site. Soil type is haplic arenosol (table 1), water table is deeper than $2 \mathrm{~m}$. Soil water potential at the depth of $40 \mathrm{~cm}$ is higher than at the depth of 10 and $20 \mathrm{~cm}$. Scots pine dominate in the first stand layer. Herbaceous vegetation - Vaccinium vitis-idae, Melampyrum pratense, Pleurozium schreberi, Hylocomnium splenden, Dicranum polysetum.

Meteorological condition. Meteorological data obtained from Nida meteorological station revealed that during the last 40 year long period mean air temperature increased by $0.05{ }^{\circ} \mathrm{C}$ per year and this trend was statistical significant ( $\mathrm{p}<0.05)$. Precipitation amount during this period also increased, but not significant and made $1.35 \mathrm{~mm}$ per year. Significant increase in air temperature especialy in April, June, August, September and November resulted in significant change in annual air temperature (3 fig). Reduction in amount of precipitation in June and September following by increase in amount of precipitation in February, July, August and October resulted in insignificant changes of annual amount of precipitation.

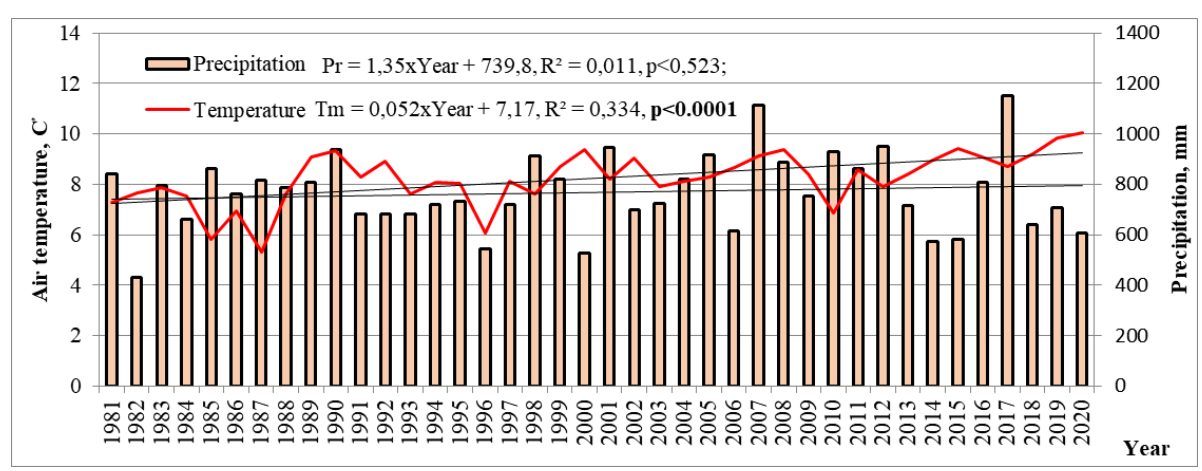

Figure 2. Precipitation and air temperature 1981-2020.

Precipitation amount and air temperature was analised for few periods during 2018-2020:

- The annual period - lasts 12 months. Begins in September, ends in August;

- The vegetation period - lasts 5 months. Begins in April, ends in August;

- The dormant period - last 7 months. Begins in September, ends in March. 

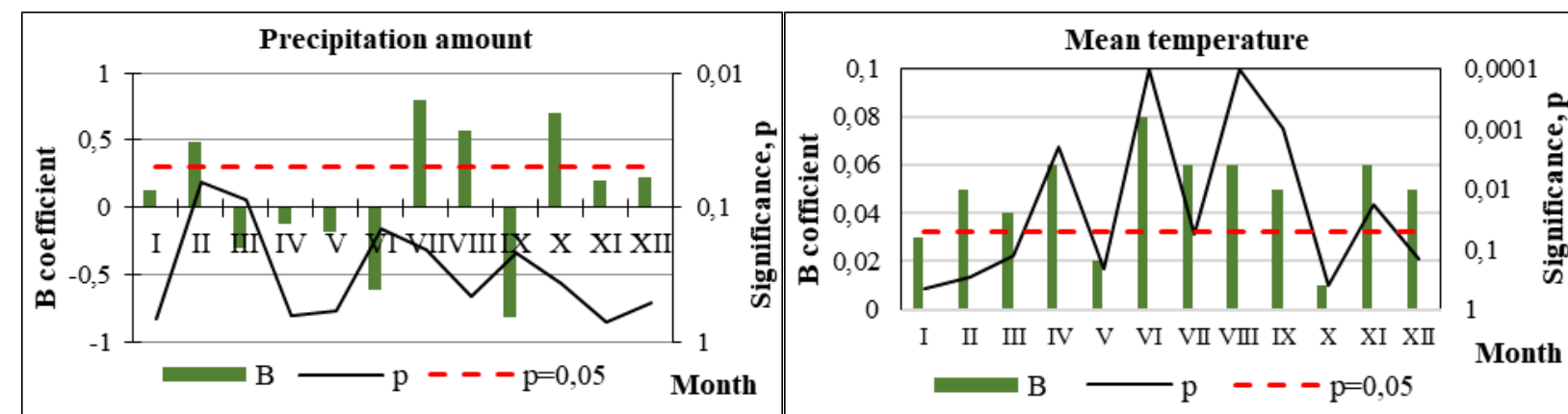

Figure 3. Slope of changes in monthly precipitation amount and mean air temperature (B coefficient of linear regression) and its significance (p)

Comparison of meteorological data during these periods allowed to identify the most humid and hot year when pine trees survived stress and the most acceptable for growth year, when pine trees regenerated.

Heat-pulse method HRM. Xylem sap flow measurements were conducted by applying the heat ratio method (Burgess et al., 2001) using sap flow meter (SFM1) from ICT International (Australia). Sap flow sensors were installed at approximately $120 \mathrm{~cm}$ stem height and sheltered with aluminium foil caps. Bark thickness was measured for each sample tree by using a bark depth gauge, sensor needles measuring at two different depths were inserted into the sapwood with a bark depth of $10 \mathrm{~mm}$ (bark removed or spacer set).

Principle of measurement - determination of temperature differences, use of cylindrical thermocouples and heater, probes inserted into the tree xylem

- uses a short pulse of heat as a tracer

- 3 probes are inserted radially into the tree sapwood middle probe generates a heat pulse and the temperature changes are measured by the other 2 probes.

The sensors measure heat pulse velocity by obtaining the ratio of downstream to upstream sapwood temperature after a heat pulse (4 fig.). Transpiration rate was analyzed at four different time periods which are presented in table 1 .

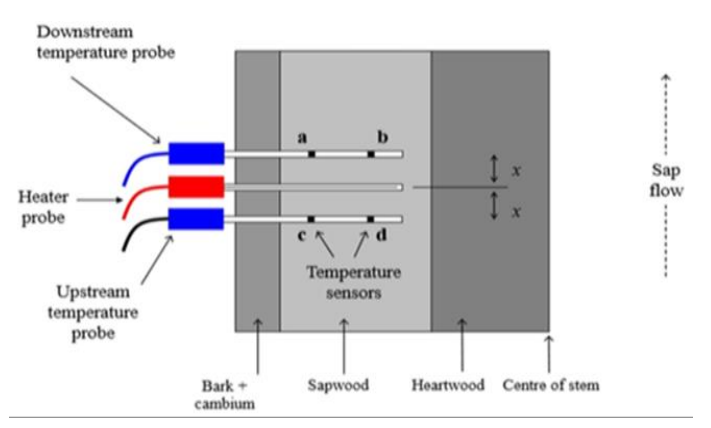

Figure 4. Heat-pulse method HRM (Burgess et al. 2001)

Table 1. Transpiration periods 2018-2020

\begin{tabular}{|c|c|c|c|c|}
\hline & SF1 & SF2 & SF3 & SF4 \\
\hline Period & $\begin{array}{l}\text { From the begining of growth to he } \\
\text { first (actual) end of growth) }\end{array}$ & $\begin{array}{l}\text { From the begining of } \\
\text { growth to the second (final) } \\
\text { end of growth }\end{array}$ & $\begin{array}{l}\text { From the begining of } \\
\text { transpiration to the end of } \\
\text { transpiration }\end{array}$ & $\begin{array}{l}\text { from the beginning of } \\
\text { transpiration to the beginning } \\
\text { of growth, }\end{array}$ \\
\hline 2018 & $\begin{array}{l}\text { Start: April } 29 \\
\text { End: August } 15\end{array}$ & $\begin{array}{l}\text { Start: April } 29 \\
\text { End: September } 26\end{array}$ & $\begin{array}{l}\text { Start: March } 11 \\
\text { End: November } 5\end{array}$ & $\begin{array}{l}\text { Start: March } 11 \\
\text { End: April } 29\end{array}$ \\
\hline 2019 & $\begin{array}{l}\text { Start: April } 24 \\
\text { End: August } 16\end{array}$ & $\begin{array}{l}\text { Start: April } 24 \\
\text { End: September } 27\end{array}$ & $\begin{array}{l}* \text { Start: February } 10 \\
\text { End: December } 21\end{array}$ & $\begin{array}{l}\text { Start: February } 10 \\
\text { End: April } 24\end{array}$ \\
\hline 2020 & $\begin{array}{l}\text { Start: April } 21 \\
\text { End: August } 6\end{array}$ & $\begin{array}{l}\text { Start: April } 21 \\
\text { End: September } 17\end{array}$ & $\begin{array}{l}\text { Start: February } 2 \\
\text { End: December } 2\end{array}$ & $\begin{array}{l}\text { Start: February } 2 \\
\text { End: April } 21\end{array}$ \\
\hline
\end{tabular}

*2019-2020 stood out as a problematic year due to the warm winter effect.

\section{Tree sesonal growth}

Radial stem annual growth at a height of $1.3 \mathrm{~m}$ was measured with manual and high-resolution dendrometers (DRL26, EMS Brno) with an accuracy of $\pm 0.1 \mathrm{~mm}$ and $0.001 \mathrm{~mm}$, respectively. The annual increment of the tree stem perimeter using was determined according to the formula:

$$
\mathrm{ZP}=\mathrm{P} 2-\mathrm{P} 1,
$$

$\mathrm{P} 1$ is the perimeter of the tree at the beginning of the vegetation period, $\mathrm{mm}$

$\mathrm{P} 2$ - tree perimeter at the end of the vegetation period, $\mathrm{mm}$.

Diameter of monitored pine trees varied between 19 and $29 \mathrm{~cm}$ at breast hight, height between $15-16 \mathrm{~m}$ and volume between 0.2-0.4 m3.

\section{RESULTS}

Meteorological condition and soil moisture during investigated period (2018-2020)

At the Nida forest enterprise mean annual air temperature in 2020 reached $10.0^{\circ} \mathrm{C}$ indicating one of the warmest years over the whole period of investigation, and dormant air temperature reached $6.7^{\circ} \mathrm{C}$ indicating the warmest dormant periods over the whole year of investigation. Data on dormant, vegetation and annual air temperature and precipitation between 2018-2020 revealed that in 2018 precipitation amount was the biggest and air temperature was the lowest in 
dormant period, but during the vegetation period air temperature and precipitation reached the highest values (Fig. 5). 2019 was evaluated as a year of drought during vegetation period. Mean annual precipitation decreased to $626 \mathrm{~mm}$ (precipitation in $2018-996 \mathrm{~mm} ; 2020-715 \mathrm{~mm}$ ) while during vegetation up to $190 \mathrm{~mm}$. In 2020, precipitation amount increased up to long term value and moisture regime recovered.

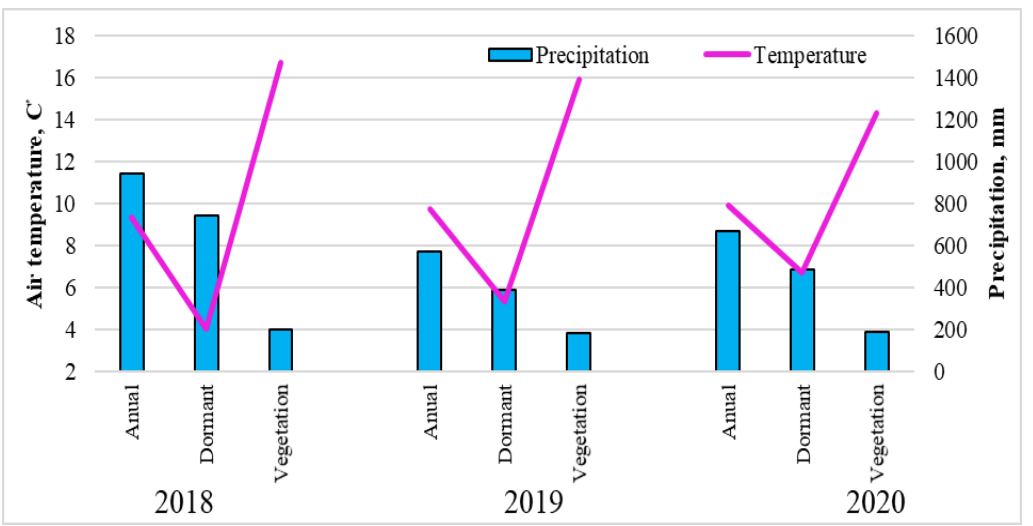

Figure 5. Average air temperature and precipitation for different period (annual, domant, vegetation) in 2018-2020.

2019 June was characterized as month with the highest mean air temperature and lowest precipitation amount (Table 2). 2020 June and July were characterized as months with the biggest amount of the precipitation i.e. moisture regime recovered.

Table 2. Average monthly air temperature and precipitation for growing season in 2018-2020 from September to August

\begin{tabular}{|l|l|l|l|l|l|l|l|l|l|l|l|l|l|}
\hline $\mathrm{T},{ }^{\circ} \mathrm{C}$ & $\mathrm{IX}$ & $\mathrm{X}$ & $\mathrm{XI}$ & $\mathrm{XII}$ & $\mathrm{I}$ & $\mathrm{II}$ & $\mathrm{III}$ & $\mathrm{IV}$ & $\mathrm{V}$ & $\mathrm{VI}$ & VII & VIII \\
\hline 2018 & 14,7 & 9,9 & 5,8 & 3,3 & $-0,2$ & $-4,3$ & $-1,4$ & 8,3 & 16,5 & 17,6 & 20,4 & 20,9 \\
\hline 2019 & 16,4 & 10,5 & 4,6 & 1,1 & $-1,2$ & 2,0 & 3,7 & 9,0 & 12,1 & $\mathbf{2 0 , 4}$ & 18,1 & 19,7 \\
\hline 2020 & 15,1 & 10,9 & 5,9 & 2,3 & 4,5 & 4,0 & 4,4 & 7,3 & 10,5 & 18,8 & 15,0 & 20,0 \\
\hline $\mathrm{P}, \mathrm{mm}$ & $\mathrm{IX}$ & $\mathrm{X}$ & $\mathrm{XI}$ & $\mathrm{XII}$ & $\mathrm{I}$ & $\mathrm{II}$ & $\mathrm{III}$ & $\mathrm{IV}$ & $\mathrm{V}$ & $\mathrm{VI}$ & VII & VIII \\
\hline 2018 & 151 & 277 & 108 & 91 & 78 & 34 & 19 & 39 & 33 & 31 & 61 & 74 \\
\hline 2019 & 69 & 99 & $\mathbf{1 8}$ & 82 & 80 & 38 & 59 & 0 & 62 & $\mathbf{2 8}$ & $\mathbf{5 1}$ & $\mathbf{4 0}$ \\
\hline 2020 & 77 & 125 & 84 & 60 & 72 & 63 & 42 & 6 & 21 & 46 & 61 & 58 \\
\hline
\end{tabular}

\section{Transpiration rate}

Meteorology was a key factor resulting in the variations in transpiration intensity. Hight air temperature and precipitation stimulated transpiration intensity in 2018 and 2020 while low precipitation reduced transpiration intensity in 2019. In 2019-2020 pine transpired all year, so, in this period it is important to emphasize that transpiration does not begin but intensified in February and started to reduc in December (Fig. 6)

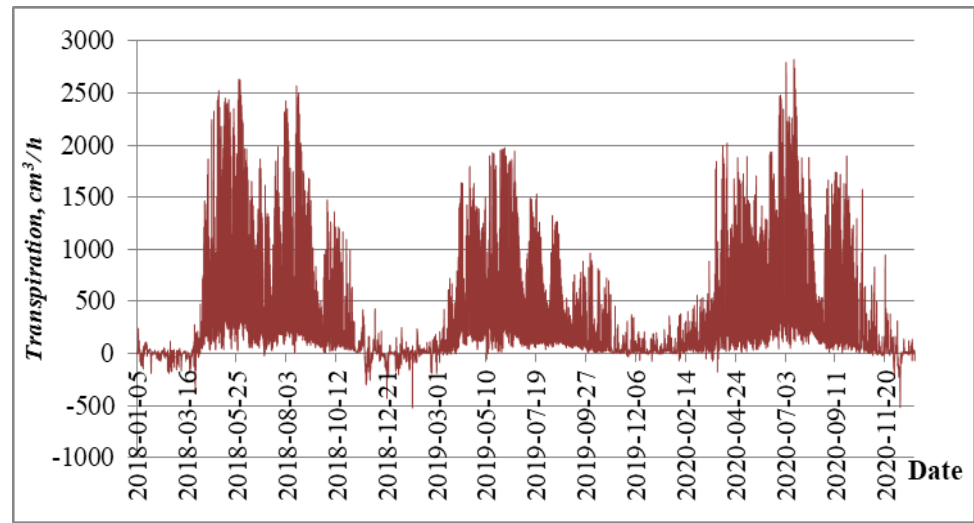

Figure 6. Pine transpiration of monitored pine trees in 2018-2020

Whole transpiration rate from the beginning up to the end was detected adding SF3 value with SF4. Obtained data revealed that whole transpiration rate in 2019 was the lowest and made 28791 per year, while the highest its value was registered in 2020, when it made 36221 per year. Analysing data on vegetation period obtained data indicated that the lowest transpiration rtate was detected also in 2019, while the most intensive transpiration rate was in 2018. The most intensive transpiration before the beginning of growth was registered in spring of 2020. These variations in transpiration rate could have had significant effect on tree water use efficiency. 
Table 3. Transpiration of monitored pine trees in 2018-2020

\begin{tabular}{|c|c|c|c|c|c|c|c|c|c|}
\hline Year & Period & Pine_1 & Pine_2 & Pine_3 & Pine_4 & Average & $\begin{array}{c}\text { Total number of } \\
\text { hours }\end{array}$ & $\begin{array}{c}\text { Total air } \\
\text { temperature, }{ }^{\circ} \mathrm{C}\end{array}$ & $\begin{array}{c}\text { Total } \\
\text { precipitation, mm }\end{array}$ \\
\hline \multirow{4}{*}{2018} & SF1, 1 & 1731.2 & 1531.0 & 2768.9 & & 2010 & 2616 & 48899.4 & 186 \\
\hline & SF2, 1 & 2215.0 & 1993.5 & 3519.5 & & 2576 & 3624 & 67905.6 & 273 \\
\hline & SF3, 1 & 2559,3 & 2279.8 & 4221.5 & & 3020 & 5760 & 82577.4 & 423.1 \\
\hline & SF4, 1 & 239.1 & 202.5 & 534.6 & & 325 & 1200 & 5906.3 & 53.8 \\
\hline \multirow{4}{*}{2019} & SF1, 1 & 1401,9 & 788.2 & 2478.1 & 1667,0 & 1556 & 2761 & 46716.8 & 176 \\
\hline & SF2, 1 & 1591.6 & 923.1 & 3051.9 & 1922,9 & 1856 & 3768 & 64150.8 & 222 \\
\hline & SF3, 1 & 2012.9 & 1203.5 & 4120.3 & 2310,0 & 2446 & 7560 & 87539.9 & 593,8 \\
\hline & SF4, 1 & 327.3 & 230.4 & 742.9 & 292,7 & 434 & 1776 & 8484.8 & 75.2 \\
\hline \multirow{4}{*}{2020} & $\mathrm{SF} 1,1$ & 1509.8 & 1184.9 & 2643.5 & 2439,3 & 1779 & 2592 & 39658.4 & 138 \\
\hline & $\mathrm{SF} 2,1$ & 2033.3 & 1673.9 & 3705.8 & 3240,9 & 2471 & 3601 & 58541.8 & 208 \\
\hline & SF3, 1 & 2460.2 & 2082.4 & 4827.7 & 3909,4 & 3123 & 7320 & 86816.1 & 485.7 \\
\hline & SF4, 1 & 328.9 & 319.1 & 849.1 & 530,5 & 499 & 1920 & 9293.3 & 104.2 \\
\hline
\end{tabular}

\section{Trees annual increment}

Pine began to grow in April when air temperature reached $7-8^{\circ} \mathrm{C}^{\circ}$, and ended first, when air temperature was about $19^{\circ} \mathrm{C}^{\circ}$ (first - actual end in August) and second, when air temperature decreased up to $10^{\circ} \mathrm{C}^{\circ}$ (second - final end of growth in October). Pine trees demonstrated the highest increment in moisture regime recovery year, i.e. in 2020. Drought was a key factor resulting in the decrease increment in pine in 2019 (7 fig).

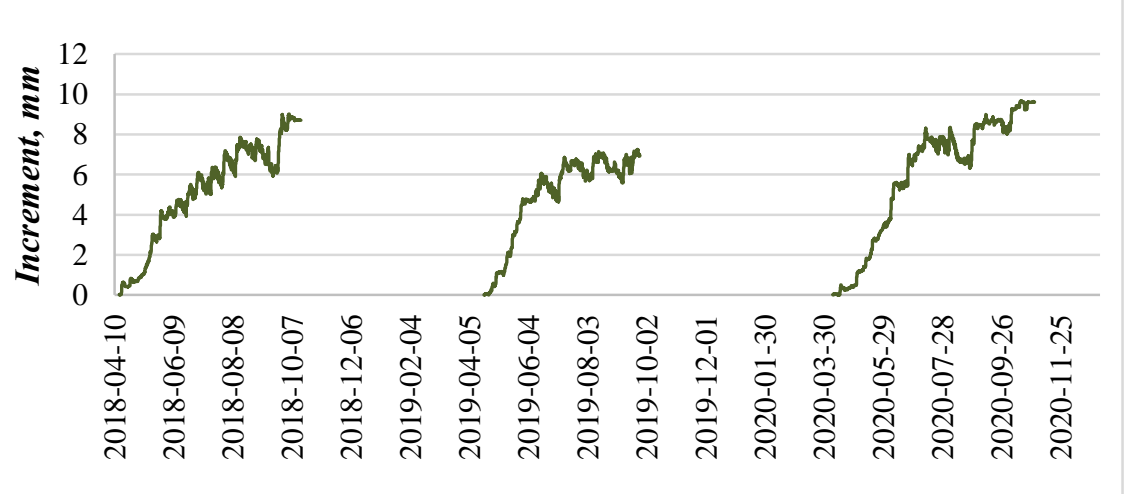

Figure 7. Pines increment 2018-2021

Data on annual volume increment of Scots pine between 2018-2020 revealed that meteorological conditions significantly resulted in variation of tree volume increment. The highest increment was in the year with a lot of precipitation and heat. The drought resulted in the lowest value of annuam stem increment in 2019 (Table 4).

Table 4. Annual volume increment of monitored trees in 2018-2021

\begin{tabular}{|c|c|c|c|c|c|}
\hline & \multicolumn{5}{|c|}{2018} \\
\hline & Pine_1 & Pine_2 & Pine_3 & Pine_4 & Average \\
\hline $\mathrm{SF} 1, \mathrm{~cm}^{3} /$ year & 5822.4 & & 5785.9 & & 5804.2 \\
\hline \multirow[t]{2}{*}{$\mathrm{SF} 2 \mathrm{~cm}^{3} /$ year } & 5989.8 & & 5849.8 & & 5919.8 \\
\hline & \multicolumn{5}{|c|}{2019} \\
\hline $\mathrm{SF} 1, \mathrm{~cm}^{3} /$ year & 6312.9 & 2650.1 & 6246.8 & 6011.5 & 5305.3 \\
\hline \multirow[t]{2}{*}{ SF2 $\mathrm{cm}^{3} /$ year } & 6092.6 & 2531.5 & 6485.9 & 6025.8 & 5283.9 \\
\hline & \multicolumn{5}{|c|}{2020} \\
\hline $\mathrm{SF} 1, \mathrm{~cm}^{3} /$ year & 6331.4 & 3450.0 & 6251.4 & 7179.9 & 5803.2 \\
\hline SF2 $\mathrm{cm}^{3} /$ year & 6815.5 & 3981.6 & 7215.8 & 8009.2 & 6505.5 \\
\hline
\end{tabular}

WUE and its evaluation in 2018-2020

Obtained data on water use efficiency shows how many liters of water a tree needs to produce $1 \mathrm{~cm}^{3}$ of wood. Meteorological condition was also key factor resulting significantly in the value of WUE. In 2018, pine used significantly more water to produce $1 \mathrm{~cm}^{3}$ of wood than in 2019. WUE of Scot pine was the highest in the driest year (2019), on very oligotrophic soils of normal moisture, indicating their proper adaptation to recent meteorological conditions in a hemiboreal forest (Table 5). Increase in tree diameter reduced values of Scots pine WUE, what means that bigger pine trees used significantly less water to produce $1 \mathrm{~cm}^{3}$ of wood. 
Table 5. Watter use efficiency $\left(1 / \mathrm{cm}^{3}\right)$ during different periods of tree ring formation

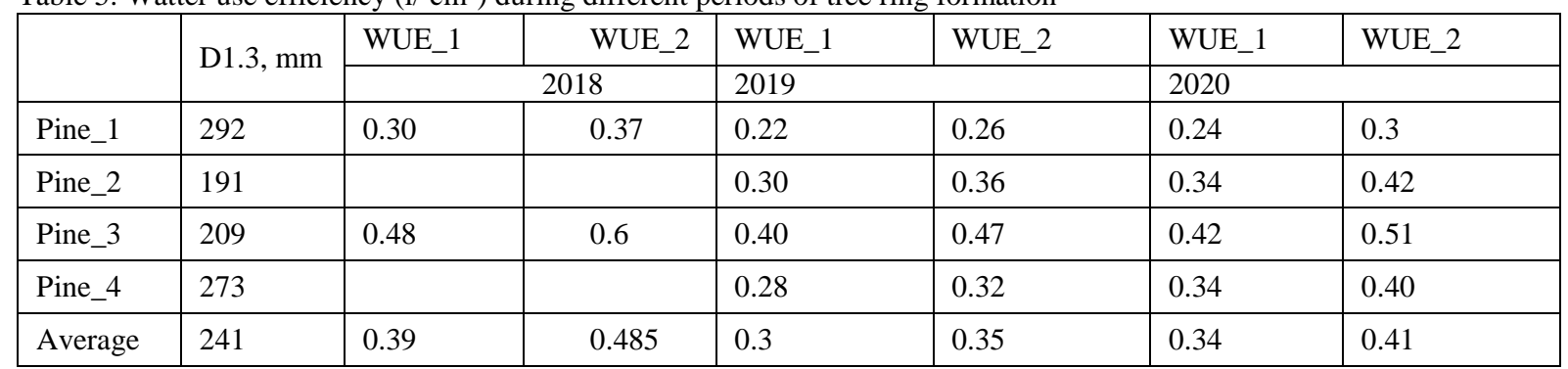

Note: WUE_1 is the water use efficiency from the biginning of growth to the first end of growth (in August) (SF1), WUE_2 is water use efficiency from the beginning of growth to the total end of growth (in October) (SF2).

\section{CONCLUSIONS}

1. Drought (2019) reduced growth and transpiration rates of Scots pine trees growing on very oligotrophic soils of normal moisture, but water use efficiency remained the highest, what means that during the drought, pine tree needed less water to produce $1 \mathrm{~cm}^{3}$ of wood. Increase in tree parameters increase in pine tree water use efficiency.

2. In the year with normal precipitation amount (2020), pine volume increment recovered and reached the highest values as well as transpiration intensity rate, but the water use efficiency reduce to the lowest values. Increase in tree parameters reduced pine tree water use efficiency during favorable for tree growth period.

3. Obtained data on WUE during different growing season revealed that Scots pine trees are well adapted to recent meteorological condition.

\section{REFERENCES}

1. Augustaitis A. 2011. Impact of Meteorological Parameters on Responses of Pine Crown Condition to Acid Deposition at Aukštaitija National Park. Baltic Forestry, Vol. 17 pp. 205-214.

2. Augustaitis A. 2021. Intra-Annual Variation of Stem Circumference of Tree Species Prevailing in Hemi-Boreal Forest on Hourly Scale in Relation to Meteorology, Solar Radiation and Surface Ozone Fluxes. Atmosphere, Vol. 12 (8), 1017. https://doi.org/10.3390/atmos12081017

3. Augustaitis A., Augustaitienė I., Baugarten M., Bičenkienė S., Girgždienė R., Kulbokas G., Linkevičius E., Marozas V., Mikalajūnas M., Mordas G., Mozgeris G., Petrauskas E., Pivoras A., Šidlauskas G., Ulevičius V., Vitas A., Matyssek R. 2018. Tree-ring formation as an indicator of forest capacity to adapt to the main threats of environmental changes in Lithuania. Science of the Total Environment, Vol. 615, pp. 1247-1261. https://doi.org/10.1016/j.scitotenv.2017.09.169

4. Augustaitis A., Augustaitiene I., Činga G., Mažeika J., Deltuvas R., Juknys R., Vitas A. 2007b. Did the Ambient Ozone Affect Stem Increment of Scots Pines (Pinus sylvestris L.) on Territories under Regional Pollution Load? Step III of Lithuanian Studies. The Scientific World Journal, Vol. 7, pp. 58-66. https://doi.org/10.1100/tsw.2007.55

5. Augustaitis A., Augustaitienè I., Deltuvas R. 2007a. Scots Pine (Pinus sylvestris L.) Crown Defoliation in Relation to the Acid Deposition and Meteorology in Lithuania. Water Air and Soil Pollution, Vol.182, pp. 335-348. https://doi.org/10.1007/s11270$\underline{007-9345-9}$

6. Augustaitis A., Augustaitienė I., Kliučius A., Pivoras G., Šopauskienė D., Girgždienė R., 2010a. The seasonal variability of air pollution effects on pine conditions under changing climates. European Journal of Forest Research, Vol. 129, pp. 431-441. https://doi.org/10.1007/s10342-009-0319-X

7. Augustaitis A., Augustaitienė I., Mozgeris G., Juknys R., Vitas A., Jasinevičienè D. 2015. Growth patterns of Scots pine (Pinus sylvestris L.) under the current regional pollution load in Lithuania. iForest, Vol. 8, pp. 509-516. https://doi.org/10.3832/ifor1267-007

8. Augustaitis A., Šopauskienė D., Baužienė I. 2010b. Direct and Indirect Effects of Regional Air Pollution on Tree Crown Defoliation. Baltic Forestry, Vol. 16, pp. 23-34.

9. Augustaitis A. 2007. Pine sawfly (Diprion pini L.) - Related changes in Scots pine crown defoliation and possibilities of recovery. Polish Journal of Environmental Studies, Vol. 16, pp. 363-369.

10. Baumgarten M., Hesse B.D., Augustaitienè I., Marozas V., Mozgeris G., Byčenkienė S., Mordas G., Pivoras A., Pivoras G., Juonytė D., Ulevičius V., Augustaitis A., Matyssek R. 2019. Responses of species-specific sap flux, transpiration and water use efficiency of pine, spruce and birch trees to temporarily moderate dry periods in mixed forests at a dry and wet forest site in the hemi-boreal zone. Journal of Agricultural Meteorology, Vol. 75, Iss. 1, pp. 13-29. https://doi.org/10.2480/agrmet.D-18-00008

11. Bond B.J., Meinzer F.C., Brooks J.R. 2008. How trees influence the hydrological cycle in forest ecosystems. Hydroecology and Ecohydrology: Past, Present and Future. Editor(s):. Wood P.J., Hannah D.M., Sadler J.P. pp. 7-28. https://doi.org/10.1002/9780470010198.ch2

12. Collins D.C., Avissar R. 1994. An evaluation with the Fourier amplitude sensitivity test (FAST) of which land-surface parameters are of greatest importance in atmospheric modelling. Journal of Climate, Vol. 7, pp. 681-703. https://doi.org/10.1175/15200442(1994)007<0681:AEWTFA>2.0.CO;2

13. Dawson T.E. 1996. Determining water use by trees and forests from isotopic, energy balance and transpiration analyses: the roles of tree size and hydraulic lift. Tree Physiology, Vol. 16, pp. 263-272. https://doi.org/10.1093/treephys/16.1-2.263 
14. Deslauriers A., Rossi S., Anfodillo T. 2007. Dendrometer and intra-annual tree growth: What kind of information can be inferred? Dendrochronologia, Vol. 25, pp. 113-124. https://doi.org/10.1016/j.dendro.2007.05.003

15. Forsius M., Posch M., Holmberg M., Vuorenmaa J., Kleemola S., Augustaitis A., Beudert B., Bochenek W., Clarke N., deWit H.A., Dirnböck T., Frey J., Grandin U., Hakola H., Kobler J., Krám P., Lindroos A.J., Löfgren S., Pecka T., Rönnback P., Skotak K., Szpikowski J., Ukonmaanaho L., Valinia S., Váňa M. 2021. Assessing critical load exceedances and ecosystem impacts of anthropogenic nitrogen and sulphur deposition at unmanaged forested catchments in Europe. Science of the Total Environment, Vol. 753, ID 141791. https://doi.org/10.1016/j.scitotenv.2020.141791

16. Granier A., Loustau D. 1994. Measuring and modelling the transpiration of a maritime pine canopy from sapflow data. A Agricultural and Forest Meteorology, Vol. 71, pp. 61-81. https://doi.org/10.1016/0168-1923(94)90100-7

17. Higgins P.A.T., Schneider S.H. 2005. Long-term potential ecosystem responses to greenhouse gas-induced thermohaline circulation collapse. Global Change Biology, Vol. 11, pp. 699-709. https://doi.org/10.1111/j.1365-2486.2005.00952.x

18. Hokka H., Penttila T., Hanell B. 1996. Effect of thinning on the foliar nutrient status of Scots pine stands on drained boreal peatlands. Canadian Journal of Forest Research, Vol. 26, pp. 1577-1584. https://doi.org/10.1139/x26-177

19. Holmberg M., Vuorenmaa J., Posch M., Forsius M., Lundin L., Kleemola S., Augustaitis A., Beudert B., Wit H.A., Dirnböck T., Evansh C.D., Frey J., Grandin U., Indriksone I., Krám P., Pompei E., Schulte-Bisping H., Srybny A., Váňa M. 2013. Relationship between critical load exceedances and empirical impact indicators at Integrated Monitoring sites across Europe. Ecological Indicators, Vol. 24, pp. 256-265. https://doi.org/10.1016/j.ecolind.2012.06.013

20. Juknys R., Augustaitis A., Venclovienė J., Kliučius A., Adomas V., Bartkevičius E., Jurkonis N. 2014. Dynamic response of tree growth to changing environmental pollution. European Journal of Forest Research, Vol. 133, pp. 713-724. https://doi.org/10.1007/s10342-013-0712-3

21. Köstner B., Biron P., Siegwolf R., Granier A. 1996. Estimates of water vapour flux and canopy conductance of Scots pine at the tree level utilising different xylem sapflow methods. Theoretical and Applied Climatology, Vol. 53, pp. 105-113. https://doi.org/10.1007/BF00866415

22. Lévesque M., Rigling A., Bugmann H., Weber P., Brang P. 2014. Growth response of five co-occurring conifers to drought across a wide climatic gradient in Central Europe. Agric. Forest Meteorology, Vol. 197, pp. 1-12. https://doi.org/10.1016/j.agrformet.2014.06.001

23. Marozas V., Augustaitis A., Pivoras A., Baumgarten M., Mozgeris G., Sasnauskienė J., Dautartė A., Abraitienė J., Byčenkienė S., Mordas G., Ulevičius V., Matyssek R. 2019. Comparative analyses of gas exchange characteristics and chlorophyll fluorescence of three dominant tree species during the vegetation season in hemi-boreal zone, Lithuania. Journal of Agricultural Meteorology, Vol. 75, Iss. 1, p. 3-12. https://doi.org/10.2480/agrmet.D-18-00004

24. Masaitis G., Mozgeris G., Augustaitis A. 2013. Spectral reflectance properties of healthy and stressed coniferous trees. iForest, Vol. 6, pp. 30-36. ttps://doi.org/10.3832/ifor0709-006

25. Masaitis G., Mozgeris, G., Augustaitis A. 2014. Estimating Crown Defoliation and the Chemical Constituents in Needles of Scots Pine (Pinus sylvestris L.) Trees by Laboratory Acquired Hyperspectral Data. Baltic Forestry Vol. 20, No 2, pp. 314-325.

26. Morén A.-S., Lindroth A., Grelle A. 2001. Water-use efficiency as a means of modelling net assimilation in boreal forests. Trees, Vol. 15, pp. 67-74 https://doi.org/10.1007/s004680000078

27. Paoletti E., Bytnerowicz A., Andersen H.-E., Augustaitis A., Ferretti M., Grulke N., Günthardt-Goergb M.S., Innes J., Johnson D., Karnosky D., Luangjame J., Matyssek R., McNulty S., Muller - Starck G., Musselman R., Percy K. 2007. Impacts of Air Pollution and Climate Change on Forest Ecosystems - Emerging Research Needs. The Scientific World Journal, Vol. 7, ID 783864. https://doi.org/10.1100/tsw.2007.52

28. Sellers P.J., Dickinson R.E., Randall D.A., Betts A.K., Hall F.G., Berry J.A., Collatz G.J., Denning A.S., Mooney H.A., Nobre C.A., Sato N., Field C.B. Henderson-Sellers A. 1997. Modeling the exchange of energy, water, and carbon between continents and the atmosphere. Science, Vol. 275, pp. 502-509. https://doi.org/10.1126/science.275.5299.502

29. Serengil Y., Augustaitis A., Bytnerowicz A., Grulke N., Kozovitz A.R., Matyssek R., Müller-Starck G., Schaub M., Wieser G., Coskun A.A., Paoletti E. 2011. Adaptation of Forest Ecosystems to Air Pollution and Climate Change. iForest, Vol. 4, pp. 44-48. https://doi.org/10.3832/ifor0566-004

30. Sicard P., Augustaitis A., Belyazid S., Calfapietra C., de Marco A., Fenn M., Bytnerowicz A., Grulke N., He S., Matyssek R., Serengil Y., Wieser G., Paoletti E., 2016. Global topics and novel approaches in the study of air pollution, climate change and forest ecosystems. Environmental Pollution, Vol. 213, pp. 977-987. https://doi.org/10.1016/j.envpol.2016.01.075

31. Swanson R.H. 1994. Significant historical developments in thermal methods for measuring sapflow in trees. Agricultural and Forest Meteorology, Vol. 72, pp. 113-132 https://doi.org/10.1016/0168-1923(94)90094-9

32. Vuorenmaa J., Augustaitis A., Beudert B., Klarke N., de Wit HA., Dirnböck T., Frey J., Forsius M., Indriksone I., Kleemola S., Kobler J., Krám P., Lindroos AJ., Lundan L., Ruoho-Airolal T., Ukonmaanaho L., Vánna M. 2017. Long-term sulphate and inorganic nitrogen mass balance budgets inEuropean ICP Integrated Monitoring catchments (1990-2012). Ecological Indicators, Vol. 76, pp. 15-29. https://doi.org/10.1016/j.ecolind.2016.12.040 